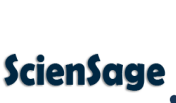

Journal of Advanced Scientific Research

Available online through https: / /sciensage.info
ISSN: 0976-9595

Short Communication

DOI: $10.55218 / J A S R .202213148$

\title{
OPTIMUM ACTIVITY TEMPERATURES OF FPASES FROM PSYCHROTOELRENT (PENICILLIUM CANESCENS AND RHODOTORULA MUCILAGINOSA) AND PSYCHROPHYLIC (PSEUDOG YMNOASCUS ROSEUS) FUNGI
}

\author{
Sangita Chouhan ${ }^{1}$, Rajkumar Ahirwar ${ }^{1}$, Tejpal Singh Parmar ${ }^{1}$, Ragini Gothalwal $^{1}$, Sanjay Sahay* ${ }^{2}$ \\ ${ }^{1}$ Department of Biotechnology, Barkatullah University, Bhopal, Madhya Pradesh, India \\ ${ }^{2}$ Sarojini Naidu Government Girl's Colllege, Bhopal, Madhya Pradesh, India \\ *Corresponding author:ss000@rediffmail.com
}

\begin{abstract}
FPAses have been isolated and studied from psychrotolerant yeast Rhodotorula mucilaginosa BPT1, Penicillium canescens BPF4 and Pseudogymnoascus roseus BPF6. BPT1 showed $100 \%$ activity at $4^{\circ} \mathrm{C}, 30^{\circ} \mathrm{C}$ and $50^{\circ} \mathrm{C}$, while that from BPF4 and BPF6 showed maximal activity at $60^{\circ} \mathrm{C}$ and $40^{\circ} \mathrm{C}$ respectively. The enzyme from BPT1 showed three peak activities, BPF4 and BPF6 showed single peak activity. While BPT1 FPAse showed $100 \%$ activity at low temperature i.e. $4^{\circ} \mathrm{C}$, rendering it very useful enzyme. The FPAses from both the other fungi also showed more than $60 \%$ residual activity at cold temperatures. The cold-activity of the enzymes makes them potential for application in simultaneous saccharification and fermentation and other industries especially food processing ones.
\end{abstract}

Keywords: Rhodotorula mucilaginosa, Penicillium canescens, Pseudogymnoascus roseus, Cold-active FPAse.

\section{INTRODUCTION}

Cellulose is an abundant bioproduct, which is chemically homopolymer of glucose. Cellulose has both crystalline and non-crystalline regions, former is very tough to be degraded but the latter is comparatively degradable under the catalytic influence of cellulases. Cellulose is a sustainable platform material that can give rise to varied products of human uses. But for that it has to be hydrolysed by cellulolytic enzymes.

Cellulases catalyze hydrolysis of plant biomass and they consist of at least three enzymes viz, or exocellulases (EC 3.2.1.91), and cellobiases or B-glucosidases (EC 3.2.1.21). Endocellulase catalyzes hydrolysis of internal glycosidic linkages randomly and exocellulase hydrolyzes sub-terminal linkages in the cellulose chains to release cellobiose either from the reducing or the non-reducing ends. Both endocellulases and exocellulases act synergistically to produce cellobiose, which subsequently split into glucoses by $ß$-glucosidase [1]. In practice applying the substrate filter paper, the combination of cellulases or FPAses are assayed.

By far thousands of the fungi have been reported to exhibit cellulolytic activity [2], commercial cellulases are mostly obtained from the fungi, Hypocrea jecorina (Trichoderma reesei) or Humicola insolens [3]. Although, cellulases from these sources are comparatively efficient ones but yet there is much scope to improve them, for example, $T$. reesei cellulases has below optimal cellobiase activity. Although, much advancement has been made to obtain and engineer cellulases from mesophilic sources for biofuel purposes, only a limited number of efforts have been made to obtain cold-active cellulases from either fungal [4-8] or bacterial [9-11] sources. Yet, there is hardly any report of prospecting cold-active cellulases for commercial uses.

All the cellulases available have optimal activity at around $60^{\circ} \mathrm{C}$, thus to have cellulolytic activity by these enzymes the temperature of the reaction mix is to be raised which consumes energy. Currently, nonconventional energy which has is deemed to mainly responsible for climate change is the main form of energy applied to industrial process. Thus cellulases with optimum activity at lower temperature would be beneficial.

\section{MATERIAL AND METHODS}

\subsection{Fungal species}

Psychrophilic fungus Pseudogymnoscus roseus BPF6 (BPF6), and psychrotolerant fungus Pencillium canesense BPF4 (BPF4) and yeast Rhodotorula mucilaginosa BPT1 (BPT1) were obtained from laboratory stock that 
was originally isolated from soil of Baramullah (J\&K) India [12].

\subsection{Maintenance of fungal species}

Fungal species were subcultured on potato dextrose agar (PDA) medium and incubated at $20^{\circ} \mathrm{C}$. For storage, fungal species were stored on PDA at $4^{\circ} \mathrm{C}$.

\subsection{Enzyme production}

Enzyme production will be carried out in $50 \mathrm{~mL}$ of basal medium, containing Czapek-Dox medium with 1\% cellulosic substrate as carbon source in Erlenmeyer flasks $(250 \mathrm{~mL})$. The medium was inoculated with above prepared inoculum of fungal cultures, followed by incubation at $20^{\circ} \mathrm{C}$ for 5 days in an orbital incubator shaker with constant shaking (120 rpm). Broth was removed each day from the third day to monitor the production of enzyme.

\subsection{Extraction of enzymes}

The broth was directly filtered through a four layered cheese cloth and the filtrate obtained was centrifuged at $5000 \mathrm{rpm}$ for $10 \mathrm{~min}$ at $4^{\circ} \mathrm{C}$. The clear supernatant was further subjected to enzyme purification.

\subsection{Purification of enzymes}

The supernatant was subjected to ammonium sulphate fractionation, active fractions were pooled and desalted. The partially purified enzyme was stored at $-20^{\circ} \mathrm{C}$ until used.

\subsection{Enzyme assays}

Filter paper ase (FPase) activity was determined as described earlier [13]. The assay mixture (total volume of $2 \mathrm{~mL})$ contained $50 \mathrm{mg}$ of Whatman No. 1 strip $(1 \times$ $6 \mathrm{~cm})$ in $1 \mathrm{~mL}$ of $50 \mathrm{mM}$ citrate buffer $(\mathrm{pH} \mathrm{4.8)}$ and 0.5
$\mathrm{mL}$ of diluted crude enzyme and incubated at $20^{\circ} \mathrm{C}$ for $30 \mathrm{~min}$.

After incubation, DNS mixture was added, boiled for 5 min and transferred immediately to a cold water bath. Then $20 \mathrm{~mL}$ of distilled water was added to the tubes, mixed and the developed colour was measured at 540 $\mathrm{nm}$ to estimate the amount of reducing sugars released [14]. The enzymatic activity of FPases was defined in international units (IU). One unit of enzymatic activity was defined as the amount of enzyme that released $1 \mu \mathrm{mol}$ reducing sugars (measured as glucose) per $\mathrm{mL}$ per min at optimum temperature.

\subsection{Protein estimation}

Protein was estimated by the method of Lowry et al. [15].

\subsection{Quality control}

All the experiments were set in triplicates and standard error was determined according to the common formula.

\section{RESULTS AND DISCUSSION}

\subsection{Fungal species}

Psychrophilic fungus Pseudogymnoscus roseus BPF6, and psychrotolerant fungus Pencillium canescens BPF4 and yeast Rhodotorula mucilaginosa BPT1 were subcultured on PDA and their morphological characters were compared with the published information [12]. They showed true to the types morphological characteristics.

\subsection{Enzyme production}

Enzyme production was monitored in each case from the third day of incubation. Enzyme production was found to reach peak level at the fifth day in case of BPT1 and BPF4, while peak was achieved at the sixth day (Fig.1).

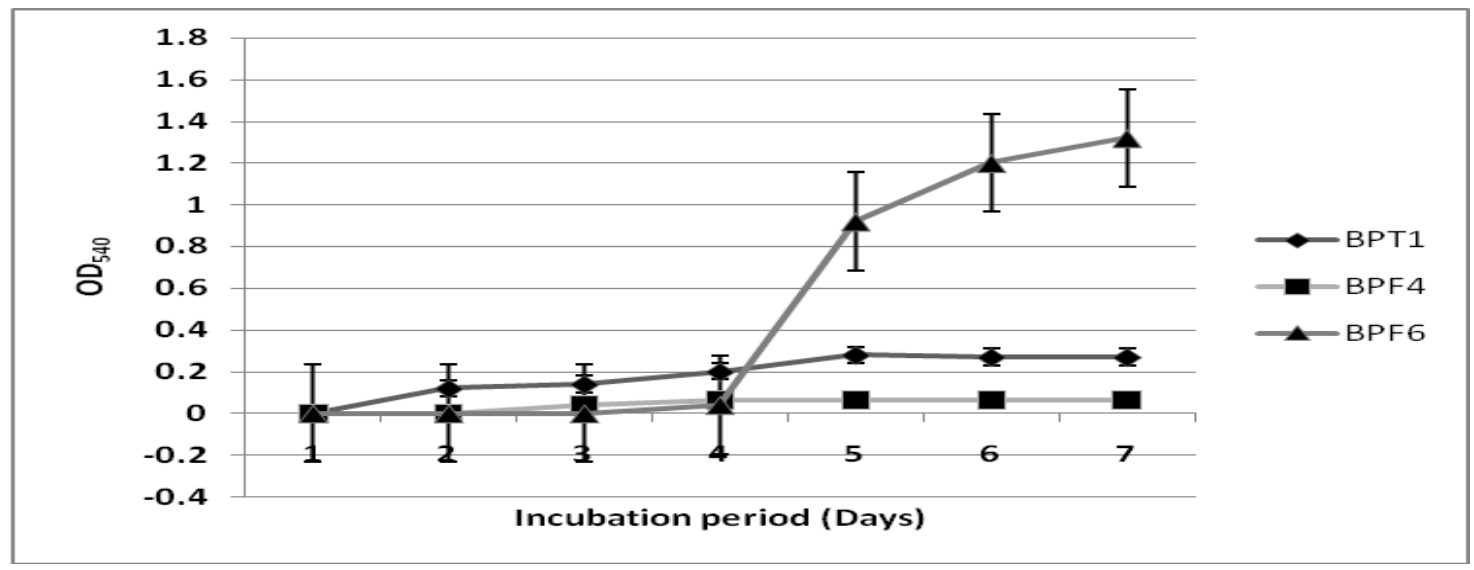

Fig. 1: FPAse production by BPT1, BPF4 and BPF6 as a function of time (days) 
The reason for this differential performance in achieving production optima is due to psychrophilic (BPF6) and psychrotolerant (BPT1 and BPF4) natures of the fungi. The growth rate of BPF6 was slower than the other two, a major reason for showing variable period in attaining optimal production. Further, the magnitude of enzyme production was also variable, the highest production was shown by BPF6 (Fig. 1).

\subsection{FPAse activity}

The FPAse activity of BPT 1 at $30^{\circ} \mathrm{C}$ and $50^{\circ} \mathrm{C}$ was found to be $4.2 \mathrm{U} / \mathrm{mg}$. That of BPF4 at $60^{\circ} \mathrm{C}$ was $2.4 \mathrm{U} / \mathrm{mg}$ and of $\mathrm{BPF} 6$ at $40^{\circ} \mathrm{C}$ was $14.4 \mathrm{U} / \mathrm{mg}$.

\subsection{Effect of temperature on FPAse activity}

FPAse activity from BPT1 showed $100 \%$ activity at $4^{\circ} \mathrm{C}$, $30^{\circ} \mathrm{C}$ and $50^{\circ} \mathrm{C}$, indicating the presence of multiple isozymes. That from BPF4 and BPF6 showed maximal activity at $60^{\circ} \mathrm{C}$ and $40^{\circ} \mathrm{C}$ respectively

(Fig. 2).
The enzyme from BPF4 and BPF6 thus seemed to have single type of activity with no isozyme.

The cold-activity of FPAse from three fungi showed variation. While BPT1 FPAse showed 100\% activity at low temperature e.g. at $4{ }^{\circ} \mathrm{C}$, rendering it very useful enzyme. The FPAses from both the other fungi also showed more than $60 \%$ residual activity at cold temperatures, equally useful biotechnologically. BPF6 FPAse is of special significance as its production rate is also high (Fig. 2) making it commercially applicable.

Earlier, cold active cellulases have been screened from a total of 88 filamentous fungal, 16 belonging to the genera Penicillium, Trichoderma, Aspergillus, and Talaromyces showed variable cellulolytic activities [16]. Cold-active cellulases have also been isolated from other fungi viz., Verticillium sp., [17] Aspergillus terrius [18]. However, for the first time, cold-active FPAses have been reported from the psychrotolerant yeast $R$. mucilaginosa, fungus $P$. canescens and psychrophilic fungus $P$ se. roseus.
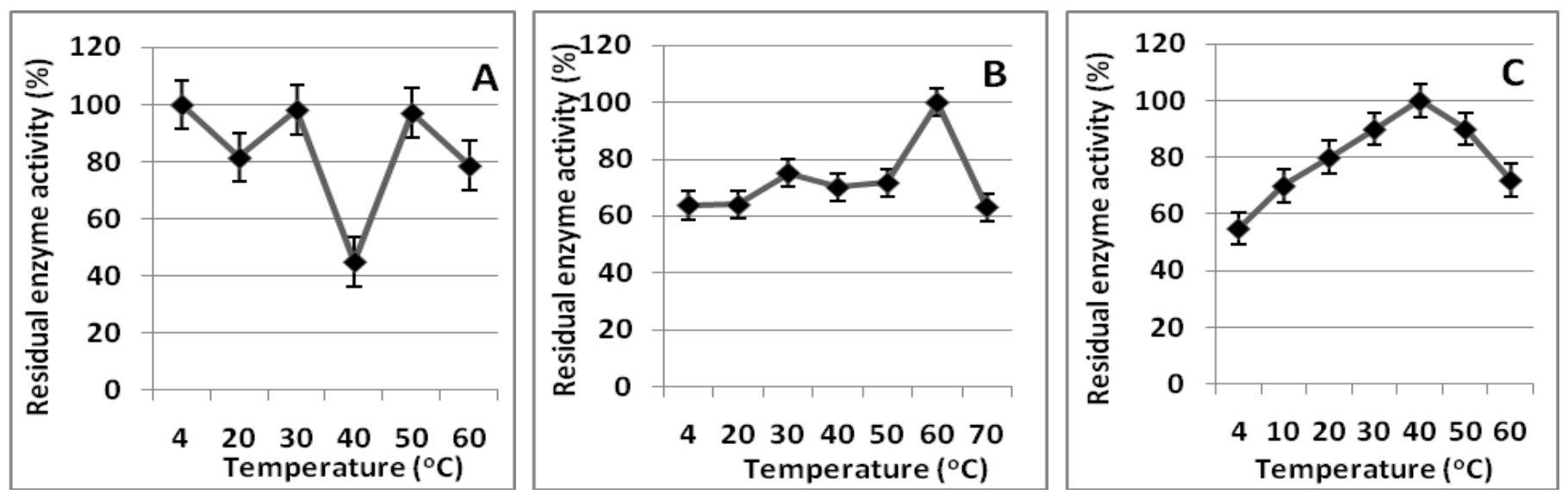

Fig. 2: Effect of temperature on FPAse activity from (A), BPT1, (B) BPF4 and(C) BPF6

Filter paper contains crystalline cellulose and is thus suitable substrate to examine the efficiency of cellulase activity [19]. Cellulose has usually both crystalline and non-crystalline parts, but it is the crystalline part whose hydrolysis poses challenge. FPAse acts on filter paper and thus its activity directly speaks of the suitability of the enzyme to hydrolyze cellulose.

Cold-active cellulases have advantages of their application in simultaneous saccharification and fermentation [20]. Commercially available cellulases show optimum activity at about $60^{\circ} \mathrm{C}$, while yeast shows optimum fermentation activity at $25^{\circ} \mathrm{C}$. Because of these differences in temperature requirements, an efficient SSF cannot be designed. But cold active cellulases have potential to permit efficient SSF.
Cellulases have multiple industrial applications including food processing industries. At low temperatures, processing of food preserves nutritional quality and aromatic profile. Cold-active FPAses thus are very important enzymes for food processing industries as well.

\section{CONCLUSIONS}

FPAses have been studied from psychrotolerant yeast $R$. mucilaginosa BPT1, P. canescens $\mathrm{BPF} 4$ and Pse. roseus BPF6. BPT1 showed $100 \%$ activity at $4^{\circ} \mathrm{C}, 30^{\circ} \mathrm{C}$ and $50^{\circ} \mathrm{C}$, while that from BPF4 and BPF6 showed maximal activity at $60^{\circ} \mathrm{C}$ and $40^{\circ} \mathrm{C}$ respectively. BPT1 FPAse showed $100 \%$ activity at low temperature i.e. $4^{\circ} \mathrm{C}$, that from both the other fungi also showed more than $60 \%$ 
residual activity at cold temperatures. The cold-activity of the enzymes makes them potential for application in simultaneous saccharification and fermentation and other industries especially food processing ones.

\section{REFERENCES}

1. Singh A. Indian J. Microbiol., 1999; 39:65-77.

2. Sukumaran RK, Singhania RR, Pandey A. J. Sci. Ind. Res., 2008; 67:898-907.

3. Wilson DB. Cellulases. In: Schaechter M, editor. Encyclopedia of Microbiology. 3rd ed. York: Academic Press; 2009. p. 252-58.

4. Dong S, Chi N, Zhang Q. Adv. Mater. Res., 2011; 183:1025-1029.

5. Duncan SM, Minasaki R, Farrell RL, Thwaites JM, Held BW, Arenz BE, et al. Antarct. Sci., 2008; 1-8.

6. Hurst JL, Pugh GJF, Walton DWH. Brit. Antarct. Surv. B, 1983; 58: 89-100.

7. Magrey A, Sahay S, Gothalwal R. Research \& Reviews: A Journal of Microbiology \& Virology, 2019; 9:38-43.

8. Singh AK, Maharana AK, Masih H, Kumar Y, Mishra SK. Res. J. Pharm. Biol. Chem. Sci., 2012; 3:977-989.
9. Maharana AK, Ray P (2013). Biosci. Biotechnol. Res. Asia, 2013; 10:267-273.

10. Singh SM, Singh SK, Yadav LS, Singh PN, Ravindra R. Arctic., 2012; 65:45-55.

11. Steiner E, Margesin R. Ann. Microbiol., 2020; 70:67.

12. Sahay S, Lone MA, Jain P, Singh P, Chouhan D, Shehzad F. Am. J. Curr. Microbiol., 2013; 1:1-13.

13. Ghose TK. Pure Appl. Chem., 1987; 59: 257-268.

14. Sahay S, Hamid B, Singh P, Ranjan K, Chouhan D, Rana RS, et al. Lett. Appl. Microbiol., 2013; 57: 115-121.

15. Lowry OH, Rosebrough NJ, Farr AL, Randall RJ. J. Biol. Chem., 1951; 193:265-275.

16. Li J-X, Zhang F, Jiang D-D, Li J, Wang F-L, Zhang Z, et al. Front. Microbiol., 2020; 11:1617.

17. Wang N, Zang J, Ming K, Liu Y, Wu Z, Ding H. Electr. J. Biotechnol., 2013; 16:12.

18. Maharana AK, Ray P. Turk J. Biol., 2015; 39:175185.

19. Wood TM, Bhat KM. Meth. Enzymol., 1988; 160:87-112.

20. Choudhary J, Singh S, Sharma A, Tiwari R, Nain L. J. Renew. Sus. Energ., 2018; 10:043102. 